\title{
Application of Quizzes “BelajarKuy” for Junior High School Based on Android
}

\author{
Dewi Nasien* \\ Department of Electrical Engineering, \\ Faculty of Engineering, Universitas \\ Riau, Indonesia \\ M. Nurul Ihsan \\ Department of Electrical Engineering, \\ Faculty of Engineering, Universitas \\ Riau, Indonesia
}

\author{
M. Hasmil Adiya \\ Informatic Engineering, Sekolah Tinggi \\ Ilmu Komputer Pelita \\ Indonesia
}

\author{
Andrio Pratama Sirait \\ Department of Electrical Engineering, \\ Faculty of Engineering, Universitas \\ Riau, Indonesia
}

Mahfuzan Hadi Wicaksono ${ }^{\mathrm{a}}$

Department of Electrical Engineering

Faculty of Engineering, Universitas

Riau, Indonesia

*corresponding author: Dewi Nasien,dewi.nasien@lecturer.unri.ac.id ; dewinasien@lecturer.pelitaindonesia.ac.id

\begin{abstract}
In today's social life, many children to students use gadgets in their daily life. Their gadgets are used mostly android. Android is utilized for all activities namely, games, social media, and others. Besides, the gadget also can be used for education such as quizzes. In this paper, BelajarKuy is proposed for education, especially for junior high school. BelajarKuy is a quiz application based on Android and it uses Java programming language. BelajarKuy contains some questions that are useful for sharpening the brains for students and teachers. Besides, BelajarKuy contains several quizzes which are Mathematics, Bahasa Indonesia, English, Science, Religion, Civic Education, and Social Education. Each quiz has twenty questions and there are four answer choices namely, A, B, C and D. However, it has a solution to the question. At the end of this quiz, students can see scores for all right and wrong questions. This is very helpful in preparing them before an exam that will be given by teachers.
\end{abstract} School

Keywords-Quizzes, BelajarKuy, Android App, Senior High

\section{INTRODUCTION}

Mobile technology has become a fundamental part of our lives. Previously, mobile devices were only used as information exchanges such as chat, SMS and social communication. Mobile devices are not only exploited by adults but it also used by students and children. The emergence of the internet makes it easy to obtain information. Many applications are made for education; one of them is proposed by [1]. This application allows accessing services, databases, announcements, registration, events, book consultations, schedules, etc. The project provides Mobile and Web-based application tools (apps) that allow online access for different users-students, instructors, and administrators. In [2], proposed a mobile application was developed for courses at the undergraduate level. The application can be used practically for 8 weeks. In other words, the findings are based on practical experience rather than a theoretical basis. Then in [3] proposed the development of assessment instrument android-based student's interest in learning Mathematics using Creative Problem Solving (CPS). In [4] proposed technology can be used as one of sources and learning media which is effective and capable of changing conventional learning into a modern one so that the learning process is no longer centered on the educator (teacher-centered), but it is subjected to the learners (student-centered).

This paper proposes, in BelajarKuy, the application of quizzes that are based on Android. This application is intended for junior high school students. This application makes easy and fun for students to face exams at school. In addition, students can practice answering questions that have four optional answers namely, A, B, C and D. There will be one correct answer from each question. BelajarKuy also provides several quizzes in Mathematics, Bahasa Indonesian, English, Science, Religion, Civil and Social Education. Each quiz has 20 questions and it is made randomly. Therefore, every question will not appear in the same sequence of questions. At the end of these quizzes, students can see the correct answer and wrong answer because BelajarKuy provides a scoreboard as a benchmark for students to see the progress that has been answered by a student. This paper is arranged as follows: Section 2 describes the literature review. Section 3, explains the research methodology. Result and discussion can be seen in Section 4. Finally, Section 5 draws a conclusion from the development of application quizzes BelajarKuy.

\section{THEORETICAL BASIC}

A quiz is a form of short questions that will be given to students to know their ability and understanding in a subject. The percentage of quiz scores is given by a teacher, but it is not as big as the final exam. However, it cannot be denied that the value of the quiz also plays a significant role at the end of semester. There are various types of questions that can be utilized for quizzes, which are contents of empty parts, multiple choices and true or false. 
Android is a software for mobile devices that has an operating system, middleware, and key applications. Android SDK provides tools and Application Programming Interface (API) to begin developing applications on the Android platform using Java programming language. Android Studio is an official Integrated Development Environment (IDE) for development of Android applications and it is open source. The launch of Android Studio was announced by Google on May $16^{\text {th }}, 2013$. At that time, Android Studio has replaced Eclipse as official IDE for developing Android applications [5]. Figure 1 shows logo of Android studio.

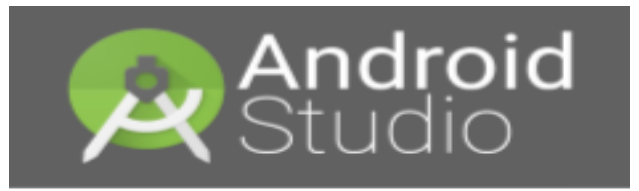

Figure 1: Android Studio

Java Development Kit (JDK) is the main item in Java programming. JDK runs systematically with Java Virtual Machine (JVM) and Java Runtime Environment (JRE). JDK is a package of tools for developing Java-based software [6].

SQLite is a software library that provides a relational database management system. The Lite in SQLite means lightweight in terms of setup, database administration and required resource. SQLite has some features which are selfcontained, server less, zero-configuration, and transactional. The flowchart is a detailed logical visual representation of all actual steps that are done to complete an entire task or process. While using a case diagram is a visual diagram representation that represents interaction between user and information system.

\section{RESEARCH METHODOLOGY}

The research methodology of BelajarKuy starting from the first stage is an analysis of specification hardware and software. Then the second stage is data collection. The third stage is design and coding, and the last stage is testing. For the specification hardware specification as follows: processor i3 $3^{\text {rd }}$ generation $2.2 \mathrm{GHz}$ and Random Access Memory (RAM) $8 \mathrm{~GB}$. To run this application, minimum android specification is Android version above 4.1 Jelly Bean and RAM $512 \mathrm{MB}$. Data collections of BelajarKuy is obtained from National exam books of junior high school. For design of BelajarKuy is shown in Figure 3 starting with login, choose subjects, answer questions, see result and lastly see scoreboard.

After a user enters BelajarKuy, 7 subjects will be displayed than can select the desired subject. The application shows some questions and each question there is only one correct answer from 4 choices namely, A, B, C and D. The results will be exposed once a quiz is completed. From here, we can see all statistics for all subjects. After the design process is accomplished, the next stage is making programming using Android studio based on Java programming. Then test process is done repeatedly until desired system is obtained.

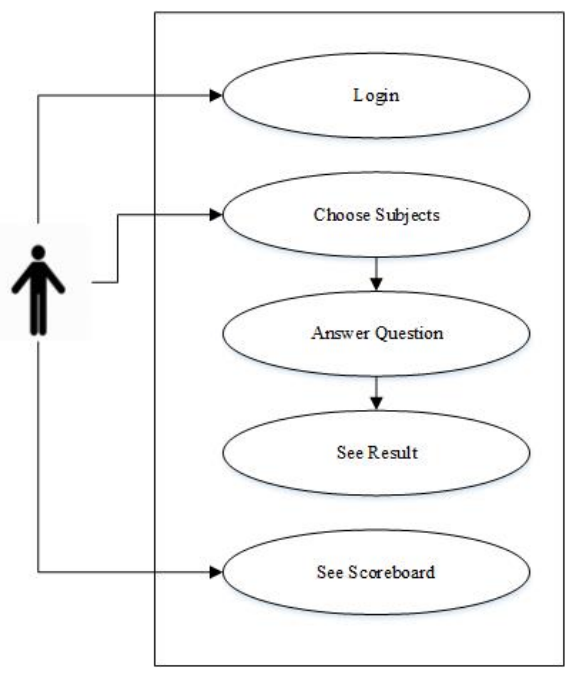

Figure 2: Use Case Diagram

\section{RESULT AND DISCUSSION}

Before starting BelajarKuy, a user is asked to create a new account as shown in Figure 4. If a user already has an account, then a user is required to enter Identity (ID) and password. If a user forgets the password, BelajarKuy will reset the password via an email that has been registered by user as shown in Figure 3.

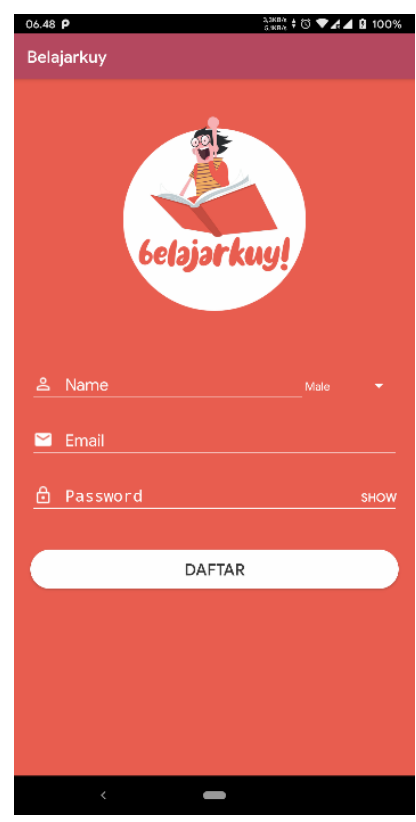

Figure 3: Register Account

After a user enters BelajarKuy, the main page will appear. The main page consists of 7 menus for junior high school namely, Mathematics, Bahasa Indonesia, English, Science, Religion, Civic Education, and Social Education. The main page is shown in Figure 5. 


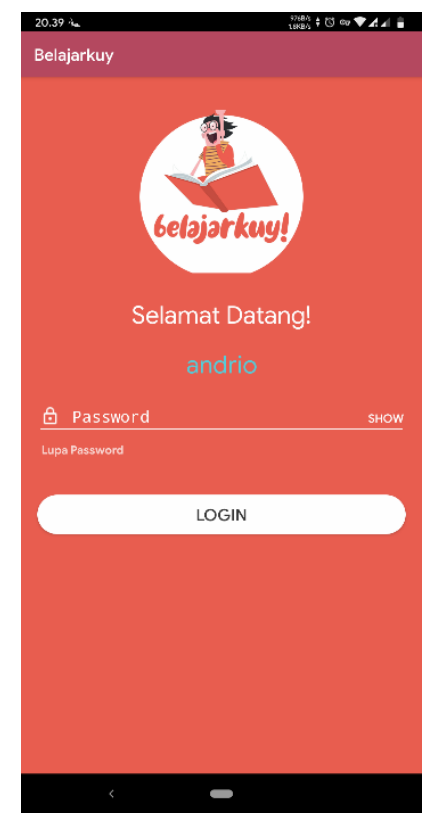

Figure 4: Login Page

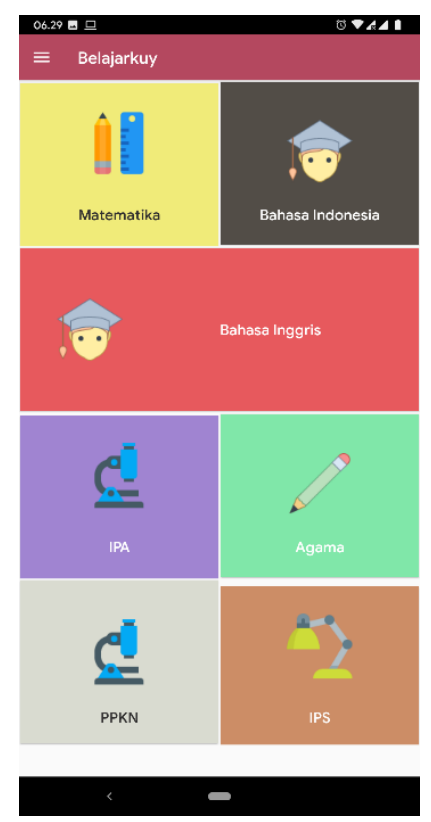

Figure 5: Main Menu Page

Figure 6 is an example of a question from a math lesson. There are four answer options available. The user only clicks on the answer that is considered correct. The right side of the corner shows the remaining time to prepare all questions in BelajarKuy system.
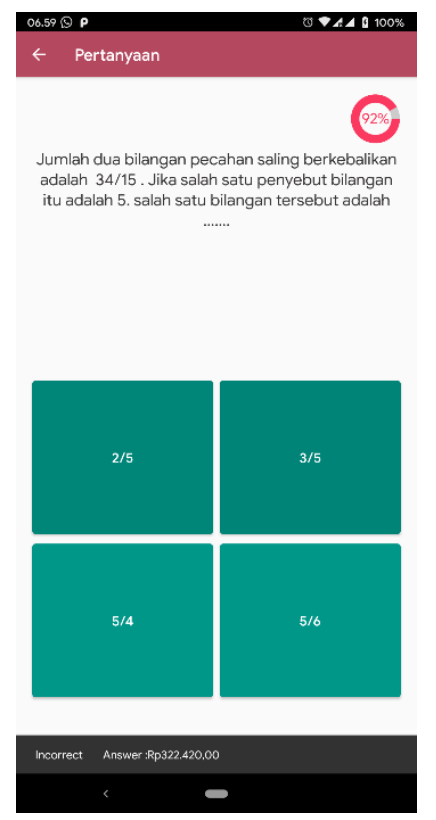

Figure 6: Question Page

After a user completes all quiz questions in BelajarKuy, the results are exposed containing several questions have been answered by the user. Eventually, a user knows number of correct and wrong answers as shown in Figure 7. Whereas, scoreboard represents the value received by user for all subjects that are illustrated in Figure 8.

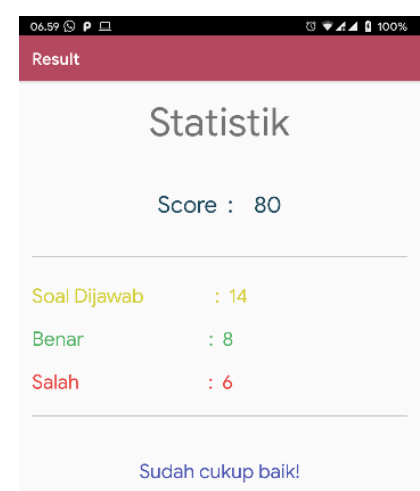

Figure 7: Result Page 


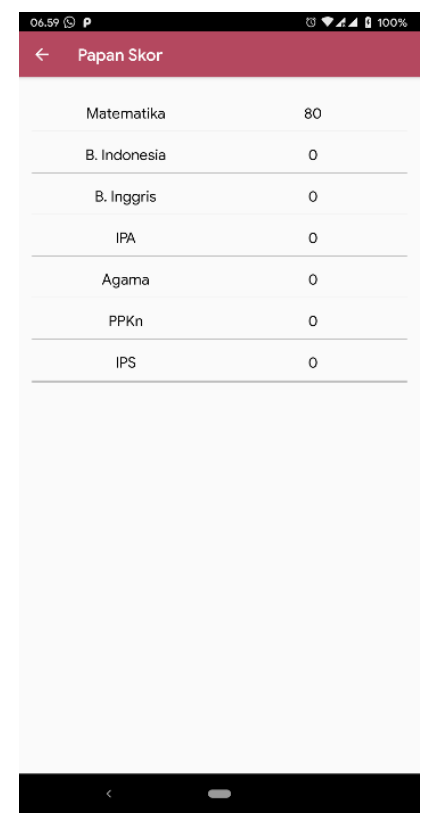

Figure 8: Scoreboard Page

\section{CONCLUSION}

BelajarKuy system can help students to study 7 subjects, namely; Mathematics, Bahasa Indonesia, English, Science, Religion, Civic Education, and Social Education. This application is based on Android so that it is more comfortable and more flexible to be used. Whenever and wherever the user can access the system. BelajarKuy is a user-friendly application since it is easy to understand. BelajarKuy offers 20 questions for each subject. The results of each item will be obtained directly by students. BelajarKuy can prepare students to face an exam in class or national exam. For future maintenance and development, this application is easy and flexible because each subsystem stands alone without any dependencies.

\section{REFERENCES}

[1] Hosam, F. El-Sofany, Samir, A. El-Seoud, Hassan, M. Alwadani, Amer, E. Alwadani, "Development of Mobile Educational Services Application to Improve Educational Outcomes using Android Technology", International Journal of Interactive Mobile Technologies (iJIM) Vols. 8, No. 2, pp: 4-9, 2014

[2] Kocakoyun, Senay Bicen, Huseyin, "Development and Evaluation of Educational Android Application", Cypriot Journal of Educational Sciences Vols. 12 No. 2, pp: 58-68, 2017.

[3] Ningrum, Eka Budi Merry Setia, Waluya, Budi., Ridlo, Saiful, "Development of Assessment Instrument Android-Based Students' Interest in Learning Mathematics SMP with CPS Model", Journal of Educational Research and Evaluation Vol. 7 No. 2, pp: 181-188, 2018.

[4] Anitah, Sri, "Technological Learning: Yuma Library", 2009.

[5] Android Developer, "Android Studio", Available: http://developer.android.com/sdk/, 2019.

[6] Tyson, Matthew, "What is JDK", Available: https://www.javaworld.com/article/3296360/what-is-the-jdkintroduction-to-the-java-development-kit.html, 2019. 